\title{
Jurist-Diction
}

Volume 2 No. 5, September 2019

Histori artikel: Submit 1 Agustus 2019; Diterima 8 Agustus 2019; Diterbitkan online 1 September 2019.

\section{Perlindungan Hukum Pihak Ketiga Yang Beritikad Baik Dalam Tindak Pidana Pencucian Uang}

\author{
Widyanti Wibowo \\ widyantiwibowo@gmail.com \\ Universitas Airlangga
}

\begin{abstract}
The foreclosure of assets that are suspected of originating from a criminal act will potentially cause harm to those who control the assets and are used as evidence in the judicial process, especially if the assets are carried out in order to recover state losses. One of the aggrieved parties is a third party with good intentions. The position of a third party in good faith is only as a witness in the judicial process and does not have a strong position in defending his property. Whereas in the UU PPTPPU Act it is not clearly and explicitly regulated regarding the accountability of third parties with good intentions and legal remedies that can be taken by third parties with good intentions to obtain legal protection. The research method used in this research is statute approach, conseptual approach, and case approach. What will be discussed in this study is regarding the third party's criminal liability with good intentions in controlling the assets resulting from crime, the legal consequences of assets resulting from crimes which are carried out by third parties with good intentions and ways that third parties can obtain legal protection in money laundering. This study also discusses the ratio decidendi of court decisions relating to third parties with good intentions found in Court Decision Number 299/ Pid.B / 2015 / PN.Pal on behalf of convicted Kurnia Widi Wibowo and Decision of the Supreme Court of the Republic of Indonesia Number 1195 K / Pid. Sus / 2014 on behalf of convicts Lutfi Hasan Ishaaq. From the results of this study, it is known that the accountability of third parties with good intentions who get legal protection in cases of money laundering. In addition, in this study it was also known that the judge's judgment (ratio decidendi) in deciding cases related to third parties with good intentions. Keywords: Crime Proceeds Asset; Good Intention; Legal Protection; Third Party.
\end{abstract}

\begin{abstract}
Abstrak
Penyitaan terhadap aset/harta kekayaan yang diduga berasal dari tindak pidana akan berpotensi menimbulkan kerugian bagi pihak-pihak yang menguasai aset/harta kekayaan yang dikuasainya dan digunakan sebagai alat bukti dalam proses peradilan, terlebih lagi apabila aset/harta kekayaan tersebut dilakukan perampasan guna mengembalikan kerugian negara. Salah satu pihak-pihak yang dirugikan adalah pihak ketiga yang beritikad baik. Kedudukan pihak ketiga yang beritikad baik dalam UU PPTPPU kurang mendapat perlindungan hukum dalam mempertahankan aset/harta kekayaan yang telah dikuasainya. Metode penelitian yang digunakan dalam penelitian ini adalah statute approach, conseptual approach,dan case approach. Adapun yang akan dibahas dalam penelitian ini adalah mengenai pertanggungjawaban pidana pihak ketiga yang beritikad baik dalam menguasai aset hasil tindak pidana, akibat hukum atas aset hasil tindak pidana yang dikusai pihak ketiga beritikad baik serta cara yang dapat ditempuh pihak ketiga untuk mendapatkan perlindungan hukum dalam tindak pidana pencucian uang. Penelitian ini juga membahas mengenai ratio decidendi putusan Pengadilan yang berkaitan dengan pihak ketiga yang beritikad baik yang terdapat dalam Putusan Pengadilan Nomor 299/Pid.B/2015/PN.Pal atas nama terpidana Kurnia Widi Wibowo dan Putusan Mahkamah Agung RI Nomor 1195 K/Pid.Sus/2014 atas nama terpidana Luthfi Hasan Ishaaq. Dari hasil penelitian ini diketahui pertanggungjawaban pihak ketiga yang beritikad baik yang mendapatkan perlindungan hukum dalam kasus tindak pidana pencucian uang. Selain itu, dalam penelitian ini juga diketahui dasar pertimbangan hakim (ratio decidendi) dalam memutus perkara terkait dengan pihak ketiga yang beritikad baik.
\end{abstract}

Kata Kunci: Aset Hasil Tindak Pidana; Itikad Baik; Perlindungan Hukum; Pihak Ketiga. 


\section{Pendahuluan}

Perkembangan teknologi yang semakin modern seiring dengan diikutinya perkembangan modus-modus kejahatan baru yang menggunakan teknologi termasuk tindak pidana pencucian uang. United National Convention Against Transnational Organized Crime (UNTOC) mendefinisikan pencucian uang sebagai konversi atau transfer property, yang diperoleh dari hasil tindak pidana. Adapun tujuan pelaku adalah untuk menyembunyikan atau menyamarkan asal properti yang ilegal atau membantu mereka menghindari konsekuensi hukum atas tindakannya atau penyembunyian atau penyamaran dari sifat, sumber, lokasi, disposisi, perpindahan atau kepemilikan atau hak yang sebenarnya sehubungan dengan property. ${ }^{1}$

Berdasarkan penjelasan umum Undang-Undang Nomor 15 Tahun 2002 jo. Undang-Undang Nomor 25 Tahun 2003 tentang Tindak Pidana Pencucian Uang, "yang dimaksud pencucian uang (money laundering) adalah upaya untuk menyembunyikan atau menyamarkan asal usul Harta Kekayaan yang diperoleh dari tindak pidana". ${ }^{2}$ Pengertian menurut Undang-Undang yang terbaru Nomor 8 Tahun 2010 tentang Pencegahan dan Pemberantasan Tindak Pidana Pencucian Uang (selanjutnya akan disebut UU PPTPPU), pencucian uang adalah segala perbuatan yang memenuhi unsur-unsur tindak pidana sesuai dengan ketentuan dalam undangundang ini yakni Pasal, 3, 4 dan Pasal 5.

Tindak Pidana Pencucian Uang sejatinya termasuk dalam salah satu tindak pidana yang mempunyai motif ekonomi. Dalam tindak pidana di bidang ekonomi, terdapat 3 (tiga) unsur, yaitu pelaku, tindak pidana yang dilakukan dan hasil tindak pidana (proceed of crime) ${ }^{3}$ Hal tersebut, terdapat dalam karakter tindak pidana

\footnotetext{
${ }^{1}$ Center for International Forestry Research, "Instrumen Anti Pencucian Uang”, https://www. cifor.org/ilea/_ref/ina/instruments/Law_Enforcement/antipencucianuang/index.htm, Juni 2010, diakses pada tanggal 23 Juli 2019.

${ }^{2}$ Undang-Undang Nomor 15 Tahun 2002 Tentang Tindak Pidana Pencucian Uang sebagaimana diubah Undang-Undang Nomor 25 Tahun 2003 Tentang Tindak Pidana Pencucian Uang (Lembaran Negara Republik Indonesia Tahun 2003 Nomor 108, Tambahan Lembaran Negara Republik Indonesia Nomor 4324), Penjelasan Umum.

${ }^{3}$ Sigit Martono, "Perlindungan Hukum bagi Pihak Ketiga yang Berikhtikad Baik Sehubungan dengan Penyitaan dan Perampasan asset dalam Perkara Tindak Pidana Korupsi dan Pencucian Uang (Studi Kasus: Putusan Pengadilan Tindak Pidana Korupsi No, 39/PID.SUS TPK 2013/PN/Jkt. Pst)", dalam Narasi: Kosakata Kosmetik Nurkholidah, FIB, UI, 2014, Januari 2015.[2].
} 
pencucian uang, yang merupakan tindak pidana lanjutan (follow up crime), yang selalu ada tindak pidana asal yang disebut predicate offense atau core crime dan tujuan pelaku menyembunyikan dan menyamarkan hasil tindak pidana agar dapat menikmati tanpa terlacak aparat penegak hukum. ${ }^{4}$

Berdasarkan Pasal 2 UU PPTPPU, tindak pidana pencucian uang dapat diperoleh dari tindak pidana asalnya yakni korupsi, penyuapan, narkotika, psikotropika, penyelundupan tenaga kerja, penyelundupan migran, di bidang perbankan, di bidang pasar modal, di bidang pengasuransian, kepabeanan, cukai, pedagangan orang, perdagangan senjata gelap, terorisme, penculikan, pencurian, penggelapan, penipuan, pemalsuan uang, perjudian, prostitusi, di bidang perpajakan, di bidang kehutanan, di bidang lingkungan hidup, di bidang kelautan dan perikanan atau tindak pidana lain yang diancam dengan pidana penjara 4 (empat) tahun atau lebih. Hal ini sesuai dengan pendapat Abd Rahman Latief yang mendeskripsikan bahwa tindak pidana pencucian uang atau money laundering termasuk salah satu kejahatan lanjutan. ${ }^{5}$ Maksudnya adalah tindak pidana pencucian uang sendiri memiliki ciri khas tertentu yakni merupakan tindak pidana lanjutan yang tidak berdiri sendiri melainkan hasil dari tindak pidana. ${ }^{6}$

Pada praktiknya, dalam penanganan tindak pidana pencucian uang sering mengalami kesulitan terkait dengan keterlibatan pihak lain, khususnya pihak ketiga yang beritikad baik. Adanya kesulitan tersebut dikarenakan UU PPTPPU belum memberikan definisi yang jelas terkait dengan pihak ketiga yang beritikad baik, sehingga seringkali menimbulkan permasalahan terkait dengan parameter pihak ketiga yang beritikad baik guna menjamin kepastian hukum. Hal tersebut berimplikasi adanya kerentanan bagi pihak ketiga yang beritikad baik dalam menguasai aset hasil tindak pidana yang diposisikan sebagai pihak yang dirugikan akibat penyitaan aset oleh penyidik sebagai barang bukti di persidangan hingga

${ }^{4}$ M. Arief Amrullah, Tindak Pidana Pencucian Uang (Money Laundering) (Bayumedia Publishing 2004).[17].

${ }^{5}$ Abd Rahman Latief, 'Money Laundering Kaitannya Dengan Pemeriksaan Tindak Pidana Asal' (2017) Vol. 5 No 8 e-Jurnal Katalogis.[129-139].

${ }^{6}$ ibid. 
jangka waktu yang tidak dapat ditentukan atau hingga menuggu proses perkara selesai. Terlebih lagi apabila aset tersebut dirampas guna mengembalikan kerugian negara. Kurangnya perlindungan bagi pihak ketiga yang beritikad baik dalam menguasai aset hasil tindak pidana pencucian uang, maka perlu adanya payung hukum guna melindungi hak-hak pihak ketiga yang beritikad baik.

\section{Metode Penelitian}

Penelitian dalam skripsi ini menggunakan tipe peneltian hukum normatif. Tujuan penelitian ini untuk menemukan kebenaran koherensi, yaitu dengan menelaah apakah aturan hukum sesuai dengan norma hukum dan adakah norma yang berupa perintah maupun larangan tersebut sesuai dengan prinsip hukum yang ada, serta apakah tindakan seseorang telah sesuai dengan norma hukum (bukan hanya aturan hukum) atau prinsip hukum. ${ }^{7}$

\section{Pertanggungjawaban Pihak Ketiga Yang Beritikad Baik dalam Menguasai Aset Hasil Tindak Pidana Pencucian Uang}

Hukum pidana mengkaji tentang perbuatan pidana, pertanggungjawaban, serta pemidanaan. Perbuatan pidana berkaitan dengan perbuatan pelaku yang telah melanggar ketentuan hukum. Konsep pertanggungjawaban dalam hukum pidana berkaitan dengan kesalahan (mens rea), dalam hal ini erat kaitannya dengan niat atau motif terselubung dari pelaku untuk melanggar ketentuan hukum. Sedangkan pemidanaan adalah pemberian hukuman bagi pelaku yang melanggar ketentuan hukum.

Menurut Roeslan Saleh, pertanggungjawaban pidana harus ditekankan pada seseorang yang dapat mempertanggungjawabkan atas perbuatannya yang melawan hukum. ${ }^{8}$ Lebih lanjut Roeslan Saleh mengatakan bahwa: Pertanggungjawaban pidana adalah sesuatu yang dipertanggungjawabkan secara pidana terhadap seseorang yang melakukan perbuatan pidana atau tindak pidana. ${ }^{9}$

\footnotetext{
${ }^{7}$ Peter Mahmud Marzuki, Penelitian Hukum Edisi Revisi (Prenadamedia Group 2016).[47].

${ }^{8}$ Roeslan Saleh, Sifat Melawan Hukum Perbuatan Pidana (Aksara Baru 1987).[74].

${ }^{9}$ ibid. [75].
} 
Hukum pidana memiliki asas yang berbunyi "geen straf zonder schuld" yang artinya adalah tiada pidana tanpa kesalahan. Maksudnya adalah seseorang hanya dapat dihukum atas perbuatannya yang melanggar hukum apabila terhadap dirinya terdapat kesalahan. Kesalahan merupakan unsur yang fundamental dalam hukum pidana. Pertanggungjawaban di hadapan hukum pidana, harus memenuhi unsur perbuatan pidana (actus reus) dan unsur kesalahan (mens rea), sehingga terhadap pelakunya dapat dikenakan pemidanaan.

Perkara tindak pidana pencucian uang seringkali melibatkan pelaku aktif dan pelaku pasif yang dapat dimintai pertanggungjawaban pidana atas perbuatannya dalam menyembunyikan atau menyamarkan aset hasil tindak pidana. Hubungan hukum dalam kasus tindak pidana pencucian uang digambarkan adanya kerja sama antara pihak kesatu sebagai pelaku aktif dan pihak kedua sebagai pelaku pasif pencucian uang untuk menikmati dan menyembunyikan hasil tindak pidana. Pihak Kesau dan pihak kedua memiliki hubungan secara langsung. Hal ini mencerminkan adanya penyertaan dan kesengajaan untuk bersekongkol dalam menyamarkan hasil tindak pidana dan menikmati keuntungan secara bersama-sama.

Penyertaan atau deelneming memiliki arti terkait dengan keikutsertaan/ terlibatnya suatu perbuatan yang masing-masing dilakukan antara orang satu dengan orang yang lainnya baik secara psikis maupun fisik sehingga melahirkan suatu tindak pidana. ${ }^{10}$ Ketentuan mengenai penyertaan diatur dalam Pasal 55 KUHP bahwa orang yang dapat dihukum sebagai pihak yang melakukan penyertaan, yakni : mereka yang melakukan, yang menyuruhlakukan, atau turutserta melakukan dan yang menganjurkan perbuatan itu. Dalam hal ini, orang yang turut melakukan memiliki keinginan yang sama untuk mencapai suatu perbuatan yang melanggar hukum. Implikasi yuridis terkait dengan adanya unsur penyertaan adalah orang yang turut serta melakukan tindak pidana dapat dikenakan pertanggung jawaban pidana.

Pihak kedua yang turut serta menyembunyikan atau menyamarkan aset hasil tindak pidana tersebut akan berhubungan dengan pihak lain, yakni pihak ketiga.

\footnotetext{
${ }^{10}$ Adam Chazawi, Pelajaran Hukum Pidana Bagian I (Raja Grafindo Persada 2002).[73].
} 
Pihak ketiga adalah pihak diluar dari diri pihak kesatu dan pihak kedua. Maksudnya adalah pihak ketiga tidak mengenal atau tidak memiliki hubungan secara langsung dengan pihak kesatu dan menguasai aset yang didapat dari pihak kedua yang mengetahui dan menduga bahwa aset tersebut berasal dari tindak pidana.

Pihak ketiga yang menguasai aset hasil tindak pidana akan dirugikan manakala asetnya disita oleh penyidik sebagai barang bukti di persidangan sampai jangka waktu yang tidak dapat diketahui bahkan harus menunggu proses perkara selesai. Kerugian pihak ketiga akan semakin besar apabila asetnya yang disita tersebut dilakukan perampasan guna mengembalikan kerugian negara. Pihak ketiga dapat dilindungi hukum untuk mempertahankan aset yang dikuasainya manakalah memiliki itikad baik. Terdapat tolak ukur atau parameter pihak yang beritikad baik dalam perspektif hukum mengenai itikad baik dalam hal jual-beli. Tolak ukur pembeli beritikad baik yang dilindungi hukum mengenai objek tanah berdasarkan Surat Edaran Mahkamah Agung (SEMA) Nomor 4 Tahun 2016 Tentang Pemberlakuan Rumusan Hasil Rapat Pleno Kamar Mahkamah Agung Tahun 2016 sebagai Pedoman Pelaksanaan Tugas Bagi Pengadilan yang terdapat di dalam rumusan hukum kamar perdata nomor 4 mengenai pengertian pembeli beritikad baik sebagaimana tercantum dalam kesepakatan kamar perdata tanggal 9 Oktober 2014 pada huruf a yang telah disempurnakan sebagai berikut:

1. Melakukan jual beli atas objek tanah tersebut dengan tata cara/prosedur dan dokumen yang sah sebagaimana telah ditentukan peraturan perundangundangan yaitu:

a. Pembelian tanah melalui pelelangan umum, atau;

b. Pembelian tanah dihadapan Pejabat Pembuat Akta Tanah (sesuai dengan ketentuan Peraturan Pemerintah Nomor 24 tahun 1997) atau;

c. Pembelian terhadap tanah milik adat atau yang belum terdaftar yang dilaksanakan menurut ketentuan hukum adat yaitu:

- dilakukan secara tunai dan terang yakni di hadapan / diketahui Kepala Adat/Kepala Desa/Lurah setempat.

- didahului dengan penelitian mengenai status tanah objek jual beli dan berdasarkan penelitian tersebut menunjukkan bahwa tanah objek jual beli adalah milik penjual.

d. Pembelian dilakukan dengan harga yang layak. 
2. Melakukan kehati-hatian dengan meneliti hal-hal berkaitan dengan objek tanah yang diperjanjikan antara lain:

a. Penjual adalah orang yang berhak/memiliki hak atas tanah yang menjadi objek jual beli, sesuai dengan bukti kepemilikannya, atau;

b. Tanah/objek yang diperjualbelikan tersebut tidak dalam status disita, atau;

c. Tanah objek yang diperjualbelikan tidak dalam status jaminan/hak tanggungan, atau;

d. Terhadap tanah yang bersertifikat, telah memperoleh keterangan dari Badan Pertanahan Nasional (BPN) dan riwayat hubungan hukum antara tanah tersebut dengan pemegang sertifikat.

Apabila menilik lebih dalam ketentuan SEMA No 4 Tahun 2016, sejatinya ketentuan angka 1 dan angka 2 dapat diterapkan terhadap objek lain yang bukan tanah, yakni benda bergerak yang terdaftar. Perluasan tersebut dikarenakan benda bergerak yang terdaftar memiliki surat-surat resmi dan mekanisme dalam jual-beli yang hampir sama dengan tanah. Ketentuan tersebut disesuaikan sesuai dengan objeknya masing-masing.

Pihak ketiga yang telah memenuhi ketentuan SEMA No. 4 tahun 2016 tersebut juga harus dibuktikan ada atau tidaknya kesalahan dalam menguasai aset hasil tindak pidana. Konsep itikad baik dalam hukum pidana erat berkaitan dengan unsur kesalahan (mens rea). Unsur kesalahan (mens rea) mengindikasikan bahwa orang melakukan perbuatan melawan hukum dilakukan secara sadar. Artinya orang tersebut "mengetahui" dan "menghendaki" adanya perbuatan yang akan melanggar hukum. Satochid Kartanegara berpendapat bahwa opzet willens en weten yang artinya dikehendaki dan diketahui. ${ }^{11}$ Maksudnya adalah seseorang dalam melakukan perbuatannya haruslah menghendaki perbuatannya dan secara sadar menginsafi atau mengetahui akibat yang ditimbulkan dari perbuatan yang telah dilakukannya. ${ }^{12}$ Lebih lanjut Satocid Kartanegara menjelaskan mengenai maksud "kehendak" yang ditujukan terhadap (a) perbuatan yang dilarang, dan (b) akibat yang dilarang. ${ }^{13}$

${ }^{11}$ Satochid Kartanegara, Hukum Pidana, Kumpulan Kuliah Bagian Dua (Balai Lektur Mahasiswa 1998).

${ }^{12} \mathrm{ibid}$.

${ }^{13}$ ibid. 
Hal ini menunjukkan adanya bentuk kesengajaan maupun kelalaian dalam suatu delik. Bentuk kesengajaan ini merupakan niat atau sikap batin dari seseorang yang tercermin melalui rangkaian perbuatan.

Berdasarkan uraian tersebut diatas, pihak ketiga dapat dikatakan memiliki itikad baik manakala telah memenuhi ketentuan SEMA No. 4 Tahun 2016 dan telah terbukti tidak memiliki mens rea. Pihak ketiga yang beritikad baik tidak dapat dikenakan pertanggungjawaban dan akan mendapatkan perlindungan hukum yakni dengan pengembalian aset yang disita oleh Pengadilan. Sedangkan pihak ketiga yang tidak beritikad baik harus mempertangungjawabkan perbuatannya dengan menerima konsekuensi hukum bahwa aset/harta kekayaannya yang disita oleh Pengadilan haruslah dirampas oleh negara.

\section{Cara Yang Dapat Ditempuh Pihak Ketiga Untuk Mendapatkan Perlindungan Hukum Dalam Tindak Pidana Pencucian Uang}

UU PPTPPU telah mengakui secara eksplisit terkait adanya pihak ketiga yang dimungkinkan terlibat dalam suatu kasus tindak pidana pencucian uang yang diatur dalam Pasal 67. Adapun rumusan Pasal 67 UU PPTPPU berkaitan dengan kewenangan pihak ketiga yang dapat mengajukan keberatan atas penghentian sementara transaksi keuangan mencurigakan yang dilakukan oleh PPATK terkait dengan adanya indikasi tindak pidana pencucian uang. Namun, UU PPTPPU belum mengatur secara komprehensif terkait mekanisme untuk untuk melindungi pihak ketiga yang beritikad baik. Pengaturan dan pembahasannya hanya terbatas pada upaya hukum berupa surat keberatan ke Pengadilan dalam jangka waktu 20 (dua puluh) hari sejak tanggal penghentian sementara transaksi mengenai dugaan terhadap transaksi keuangan mencurigakan terkait dengan adanya indikasi tindak pidana pencucian uang sebagaimana dalam Pasal 67 ayat (1) UU PPTPPU. Kemudian apabila tidak ada pihak ketiga yang mengajukan keberatan dalam jangka waktu sebagaimana yang telah ditetapkan, maka PPATK menyerahkan penanganan harta kekayaan yang diketahui atau patut diduga merupakan hasil tindak pidana pencucian uang kepada penyidik untuk selanjutnya dilakukan penyidikan. 
UU PPTPPU juga memberikan upaya hukum berupa keberatan dalam hal yang diduga sebagai pelaku tindak pidana tidak ditemukan. Pengajuan keberatan tersebut diajukan oleh penyidik ke Pengadilan Negeri dalam jangka waktu 30 (tiga puluh) hari sejak tanggal penghentian sementara transaksi mengenai dugaan terhadap transaksi keuangan mencurigakan terkait dengan adanya indikasi tindak pidana pencucian uang sebagaimana dalam Pasal 67 ayat (2) UU PPTPPU. Namun, UU PPTPPU tidak mengatur lebih lanjut bagaimana mekanisme untuk melakukan pemeriksaan terhadap acara keberatan. Terhadap ketentuan Pasal 67 UU PPTPPU tersebut mengindikasikan bahwa masih terdapat kekosongan hukum acara dalam penegakan tindak pidana pencucian uang. Disisi lain, adanya batasan waktu yang cukup singkat sebagaimana diatur dalam Pasal 67 ayat (1) dan (2) UU PPTPPU tersebut tentunya akan semakin merugikan pihak ketiga, dimana pada kurun waktu tersebut apabila informasi atas penghentian sementara transaksi tidak sampai kepada pihak ketiga, maka pihak ketiga akan kehilangan kesempatannya dan terhadap transaksi keuangan mencurigakan tersebut selanjutnya akan dilakukan penyidikan.

Peraturan Mahkamah Agung Republik Indonesia Nomor 1 Tahun 2013 Tentang Tata Cara Penyelesaian Permohonan Penanganan Harta Kekayaan Dalam Tindak Pidana Pencucian Uang atau Tindak Pidana Lain yang selanjutnya disebut Perma No. 1 Tahun 2013 sejatinya hadir sebagai solusi untuk menjawab terkait mekanisme dalam mengajukan permohonan harta kekayaan. ${ }^{14}$ Namun yang perlu dicermati dalam Perma No 1 Tahun 2013 tersebut yakni terdapat limitasi dalam Pasal 1 yang menyatakan bahwa ketentuan dalam Perma No. 1 Tahun 2013 tersebut berlaku terhadap permohonan harta kekayaan yang diajukan oleh penyidik dalam hal yang diduga pelaku tindak pidana tidak ditemukan. ${ }^{15}$ Hal ini secara langsung menjawab kekosongan hukum yang terdapat dalam Pasal 67 ayat (2) UU PPTPPU yang mengisyaratkan apabila pelaku tindak pidana tidak ditemukan. Sedangkan

\footnotetext{
${ }^{14}$ Peraturan Mahkamah Agung Republik Indonesia Nomor 1 Tahun 2013 Tentang Tata Cara Penyelesaian Permohonan Penanganan Harta Kekayaan Dalam Tindak Pidana Pencucian Uang atau Tindak Pidana Lain (Berita Negara Republik Indonesia Tahun 2013 Nomor 711).

${ }^{15}$ ibid, Pasal 1.
} 
yang terjadi kekosongan hukum ialah Pasal 67 UU PPTPPU yang terdiri dari ayat (1), (2) dan (3), apabila Perma No. 1 Tahun 2013 hanya menjawab dari kekosongan hukum Pasal 67 ayat (2) dengan memberikan limitasi bahwa yang dapat melakukan permohonan penanganan harta kekayaan hanyalah penyidik dalam hal yang diduga sebagai pelaku tindak pidana tidak ditemukan, lantas yang menjadi pertanyaan lanjutan apakah Perma No. 1 Tahun 2013 juga dapat diterapkan untuk menjawab mengenai mekanisme penyelesaian permohonan penanganan harta kekayaan dalam Pasal 67 ayat (1) UU PPTPPU.

Menilik lebih dalam Pasal 67 UU PPTPPU masuk dalam Bab VII Tentang Pemeriksaan dan Penghentian Sementara Transaksi. Hal ini mengindikasikan bahwa adanya dugaan terhadap transaksi keuangan mencurigakan yang mana masih dalam tahapan penyelidikan. Hal ini dipertegas dalam Pasal 64 ayat (2) yang substansinya bahwa dalam hal ditemukan adanya indikasi tindak pidana pencucian uang atau tindak pidana lain, PPATK menyerahkan hasil pemeriksaan kepada penyidik untuk dilakukan penyidikan. PPATK diberikan kewenangan untuk melakukan pemeriksaaan terhadap transaksi keuangan mencurigakan yang memiliki indikasi adanya tindak pidana pencucian uang serta dapat meminta kepada penyedia jasa keuangan untuk menghentikan sementara seluruh atau sebagian transaksi apabila terbukti adanya tindak pidana pencucian uang. Dengan ini sejatinya telah terdapat upaya perlindungan bagi pihak ketiga dimulai dari tahap penyelidikan berupa pengajuan keberatan dimana apabila terdapat kerugian terhadap penghentian transaksi keuangan yang berdampak pada pihak ketiga tersebut.

Upaya pelindungan terhadap pihak ketiga juga terdapat pada Pasal 79 ayat (6) UU PPTPPU yang menyatakan bahwa setiap orang yang berkepentingan dapat mengajukan keberatan kepada Pengadilan yang telah mengajukan penetapan. Dalam hal ini penetapan yang dimaksud atas perampasan harta kekayaan yang telah disita. Dengan adanya perampasan, artinya hal ini terjadi setelah adanya putusan hakim yang menyatakan bahwa terdakwa terbukti secara sah dan meyakinkan telah melakukan tindak pidana pencucian uang, sehingga harta kekayaan yang sebelumnya disita kemudian dilakukan perampasan. Namun terdapat limitasi dalam 
Pasal 79 ayat (4) dan (5) yaitu dalam hal terdakwa meninggal dunia sebelum putusan dijatuhkan, dan terdapat bukti yang cukup kuat bahwa yang bersangkutan terbukti telah melakukan tindak pidana pencucian uang, maka hakim dapat memutuskan perampasan harta kekayaan, yang mana dalam kondisi ini ditegaskan dalam Pasal 79 ayat (5) bahwa tidak ada upaya hukum. Jadi upaya hukum yang dimaksud dalam Pasal 79 ayat (6) tersebut hanya dapat dimohonkan apabila terdakwa masih hidup. Kemudian terdapat batasan waktu untuk dapat mengajukan keberatan ke Pengadilan yakni dalam waktu 30 (tiga puluh) hari sejak tanggal putusan Pengadian. Terhadap pihak yang merasa berkepentingan dapat mempersiapkan diri untuk mengajukan surat keberatan atas harta yang dilakukan perampasan oleh Pengadilan.

Pihak-pihak yang berkepentingan sebagaimana yang dimaksud pada Pasal 79 ayat (6) UU PPTPPU di sini adalah pihak yang memiliki hubungan dengan harta kekayaan dan merasa dirugikan atas dirampasnya harta kekayaan tersebut, seperti pihak ketiga. Pihak ketiga akan mendapatkan perlindungan hukum manakala ia memiliki itikad baik. Pihak ketiga ini merupakan pemilik sah atas harta/asset yang dijadikan barang bukti di Pengadilan dan kemudian dirampas oleh negara berdasarkan putusan hakim.

Upaya hukum yang dapat ditempuh oleh pihak yang beritikad baik ialah dengan mengajukan permohonan surat keberatan baik masih dalam tahap penyelidikan yaitu atas pemeriksaan dan penghentian sementara transaksi maupun sudah adanya putusan hakim yang sah. Adapun hukum acara mengenai pengajuan surat keberatan telah diatur lebih lanjut dalam Perma No 1 Tahun 2013. Surat keberatan tersebut diajukan secara terlulis dan ditujukan kepada Ketua Pengadilan Negeri. Adapun Pengadilan Negeri yang berwenang memeriksa, mengadili dan memutus permohonan penanganan harta kekayaan adalah Pengadilan Negeri yang daerah hukumnya meliputi tempat keberadan harta kekayaan sebagaimana dimaksud dalam Pasal 5 ayat (1) Perma No 1 Tahun 2013. Namun, dengan adanya limitasi yang diberikan Perma No 1 Tahun 2013 yakni dalam hal yang diduga sebagai pelaku tindak pidana tidak ditemukan, maka akan berimplikasi terhadap syarat kelengkapan guna mengajukan penanganan harta kekayaan sebagaimana 
yang disebutkan dalam Pasal 3 yakni harus ada berita acara penghentian sementara seluruh atau sebagian transaksi terkait harta kekayaan yang diketahui atau dicurigai merupakan hasil dari tindak pidana pencucian uang, berkas perkara hasil penyidikan, dan berita acara pencarian tersangka. Ketentuan dalam Pasal 3 Perma No 1 Tahun 2013 tersebut bersifat kumulatif yakni harus terpenuhi semua persyaratannya untuk dapat mengajukan permohonan penaganan harta kekayaan.

Permohonan penanganan harta kekayaan yang telah dinyatakan lengkap oleh Ketua Pengadilan Negeri, selanjutnya akan diumumkan di papan pengumuman Pengadilan Negeri dan/atau media lain. Hal ini bertujuan untuk memberikan kesempatan bagi pihak ketiga yang merasa memiliki kepentingan untuk dapat mengajukan keberatan. Pengumuman permohonan harta kekayaan tersebut dilakukan selama 30 (tiga puluh) hari kerja, dan selama itu pula peluang bagi pihak ketiga dibuka lebar untuk mengajukan keberatan.

Permohon penanganan harta kekayaan yang telah diperiksa dan diadili oleh hakim, maka selanjutnya hakim harus memutus harta kekayaan tersebut sebagai aset negara atau dikembalikan kepada yang berhak dalam jangka waktu 7 (tujuh) hari kerja terhitung sejak hari sidang pertama sebagaimana hal ini selaras dengan Pasal 194 KUHAP. Selanjutnya putusan hakim diumumkan di papan pengumuman Pengadilan Negeri dan/atau media lain untuk kembali memberikan kesempatan kepada pihak ketiga yang merasa berhak atas harta kekayaan yang dirampas oleh Negara untuk mengajukan keberatan dalam waktu paling lama 30 (tiga puluh) hari kerja setelah putusan Pengadilan diucapkan sebagaimana tertuang dalam Pasal 11 ayat (1) Perma No 1 tahun 2013.

Keberatan atas putusan hakim mengenai permohonan penanganan harta kekayaan yang diajukan oleh pihak ketiga tersebut kembali diperiksa dan diadili oleh hakim dan memerintahkan pada pemohon keberatan untuk hadir pada persidangan dengan membawa alat-alat bukti dan/atau barang bukti yang diperlukan untuk mendukung keberatan yang diajukan. Pemohon keberatan juga harus membuktikan asal usul harta kekayan tersebut bukanlah berasal dari tindak pidana. Kehadiran pemohon keberatan tersebut bersifat wajib baik didampingi atau tidak didampingi 
oleh kuasa hukumnya untuk memberikan alasan-alasan serta membuktikan bahwa harta kekayaan yang dirampas oleh negara tersebut merupakan harta miliknya pribadi yang didapatkan dengan cara yang sah. Hal ini menimbulkan implikasi yuridis apabila pemohon keberatan tersebut tidak hadir sendiri dalam persidangan, maka hakim menyatakan keberatan yang diajukan tersebut gugur dan putusan yang dimohonkan keberatan tetap berlaku. Adapun putusan hakim atas permohonan keberatan tersebut bersifat final dan mengikat sebagaimana dijelaskan dalam Pasal 18 Perma No. 1 Tahun 2013.

Sejatinya ketentuan yang telah diatur dalam Perma No. 1 Tahun 2013 tersebut telah menjawab kekosongan hukum terkait hukum acara atau prosedur pengajuan keberatan sebagaimana disebutkan dalam Pasal 67 UU PPTPPU. Namun, adanya limitasi dalam Pasal 1 Perma No. 1 Tahun 2013 tersebutlah yang kemudian membatasi Perma No. 1 Tahun 2013 untuk dapat diterapkan dengan keadaan apapun, khususnya keadaan dimana terdapat pelaku yang diduga telah melakukan tindak pidana sebagaimana sesuai dengan keadaan yang digambarkan pada Pasal 67 ayat (1) UU PPTPPU. Sehingga, PERMA No. 1 Tahun 2013 tidak dapat semerta merta diterapkan untuk menjawab Pasal 67 ayat (1) UU PPTPPU.

Mencermati kedudukan PERMA dalam hirarki peraturan perundang-undangan, bahwa kedudukan PERMA berada jauh dibawah UU. Pengaturan yang terdapat di dalam PERMA sejatinya tidak mengikat para pihak, karena hanya bersifat sebagai pedoman atau rujukan bagi hakim yang menangani perkara terkait dengan pihak ketiga dalam tindak pidana pencucian uang. Dalam hal ini, pengaturan mekanisme untuk menjawab kekosongan hukum yang terdapat di dalam Pasal 67 UU PPTPPU seharusnya diatur dalam bentuk undang-undang pula. Namun mengingat dalam pembentukan undangundang sendiri membutuhkan waktu yang lama, sedangkan dalam praktik perlu segera diadakan suatu payung hukum untuk menjamin dam melindungi kepentingan pihak ketiga yang beritikad baik, maka dapat juga pengaturan terkait dengan mekanisme yang akan menjawab Pasal 67 diatur dalam bentuk Perarutan Pemerintah (PP) atau Peraturan Presiden (Perpres) yang merupakan peraturan pelaksana dan memiliki waktu pembuatan yang relative lebih singkat dibandingkan dengan UU. 


\section{Ratio Decidendi Putusan Pengadilan Berkaitan Dengan Pihak Ketiga Yang Beritikad Baik}

Penelitian ini menganalisis Putusan Pengadilan Negeri Palu Nomor 299/ Pid.B/2015/PN.Pal atas nama terdakwa Kurnia Widi Wibowo alias Widi dan Putusan Mahkamah Agung RI Nomor 1195K/Pid.Sus/2014 atas nama terdakwa Luthfi Hasan Ishaaq berkaitan dengan pihak ketiga yang beritikad baik.

Dalam Putusan Pengadilan Negeri Palu Nomor 299/Pid.B/2015/PN.Pal hakim mempertimbangan pihak ketiga sebagai pembeli yang tidak mengetahui bahwa mobil Kijang Inova yang dibuat pelunasan atas utang tersebut berasal dari tindak pidana penggelapan. Ketidak tahuan tersebut diyakini oleh majelis hakim yang memutus perkara adalah suatu hal yang mencerminkan bahwa pembeli tersebut tidak memiliki kesengajaan untuk menikmati objek yakni mobil Innova DN 303 AA yang berasal dari tindak pidana. Dalam hukum pidana, kesalahan terletak pada perbuatan pelaku dan kesalahan, dimana dalam hal ini tiadanya kesengajaan Dewa Gede Mulyawan untuk ikut menikmati mobil Inova DN 303 AA sebagai hasil dari kejahatan yang membuat hakim yakin bahwa Dewa Gede Mulyawan merupakan pihak yang memiliki itikad baik. Sehingga perlindungan hukum bagi pihak yang beritikad baik dalam Perjanjian Jual Beli berdasarkan Putusan No: 299/Pid.B/2015/ PN.Pal yakni hakim menyatakan mobil Kijang dengan Plat Nomor DN 303 tersebut dikembalikkan kepada Dewa Gede Mulyawan.

Berdasarkan Putusan Mahkamah Agung RI Nomor 1195K/Pid.Sus/2014 diketahui bahwa pihak ketiga yang mengusai aset hasil tindak pidana tidak selalu dilindungi oleh hukum. Hal tersebut dikarenakan hakim telah membuktikan bahwa pihak ketiga memiliki mens rea untuk ikut menikmati dan menyembunyikan aset hasil tindak pidana. Dalam perkara ini terdakwa Lutfi Hasan Ishaaq membeli mobil Nissan Frontier Necara warna hitam B 9051 QI dari Hilmi Aminuddin dengan menggunakan uang hasil tindak pidana korupsi. Mobil Nissan Frontier Necara warna hitam B 9051 QI tersebut dibeli terdakwa dengan menggunakan atas nama Rintala Sikayo, sehingga Rintala sikayo menguasai mobil tersebut. 
Rintala Sikayo merupakan asisten terdakwa. Sebagai asisten pribadi, Rintala Sikayo patut mengetahui bahwa mobil tersebut berasal dari tindak pidana. Pembelian mobil Nissan Frontier Necara warna hitam B 9051 QI yang menggunakan nama Rintala Sikayo tersebut dapat diindikasikan bahwa Rantala Sikayo secara sadar telah mengetahu dan menghendaki untuk turut serta menyamarkan aaset hasil tindak pidana. Sehingga hal tersebut mencerminkan bahwa Rantala Sikayo tidak memiliki itikad baik dalam perolehan atau mengusai mobil Nissan Frontier Necara warna hitam B 9051 QI. Sesuai dengan pertimbangan hakim bahwa mobil Nissan Frontier Necara warna hitam B 9051 QI dikategorikan sebagai hasil dari tindak pidana korupsi. Dengan demikian majelis hakim telah memutuskan bahwa sudah sepatutnya mobil Nissan Frontier Necara warna hitam B 9051 QI dirampas oleh negara.

Berdasarkan kedua putusan tersebut membuktikan bahwa kedudukan pihak ketiga dalam tindak pidana pencucian uang dapat menjadi pihak yang beritikad baik dan pihak yang tidak beritikad baik atau pelaku pasif.

\section{Kesimpulan}

Tolak ukur pihak ketiga dikatakan beritikad baik manakala memenuhi tata cara/prosedur dan dokumen yang sah sebagaimana dimaksud dalam SEMA No 4 Tahun 2016. Namun harus tetap dibuktikan bahwa pihak ketiga tidak mengetahui dan menghendaki bahwa aset/harta kekayaan yang telah dikuasainya adalah berasal dari hasil tindak pidana pencucian uang, sehingga pihak ketiga yang beritikad baik tidak dapat dikenakan pertanggungjawaban dan akan mendapatkan perlindungan hukum yakni dengan pengembalian aset/harta kekayaan yang disita oleh Pengadilan. Pihak ketiga yang menguasai aset/harta kekayaan hasil tindak pidana dalam perkara tindak pidana pencucian uang berpotensi menjadi pelaku pasif sebagaimana dimaksud dalam Pasal 5 UU PPTPPU manakala terbukti adanya mens rea untuk menyembunyikan atau menyamarkan aset. Pihak ketiga yang beritikad tidak baik dapat menjadi pelaku pasif, sehingga dipertanggunngjawabkan secara hukum dan aset yang dikuasai tersebut akan dirampas oleh negara. 
Ratio decidendi Putusan Pengadilan Negeri Palu Nomor 299/Pid.B/2015/ PN.Pal berkaitan dengan pihak ketiga yang beritikad baik adalah ketidaktahuan pihak ketiga terhadap asal-usul aset/harta kekayaan yang telah dikuasainya berasal dari tindak pidana. Sedangkan ratio decidendi Putusan Mahkamah Agung RI Nomor 1195K/Pid.Sus/2014 berkaitan dengan pihak ketiga yang beritikad tidak baik adalah adanya mens rea dan penyertaan pihak ketiga yang turut menikmati atau menyamarkan aset/harta kekayaan hasil tindak pidana.

\section{Daftar Bacaan}

\section{Buku}

M. Arief Amrullah, Tindak Pidana Pencucian Uang (Money Laundering) (Bayumedia Publishing 2004).

Peter Mahmud Marzuki, Penelitian Hukum Edisi Revisi (Prenadamedia Group 2016).

Roeslan Saleh, Sifat Melawan Hukum Perbuatan Pidana (Aksara Baru, 1987).

Adam Chazawi, Pelajaran Hukum Pidana Bagian I (Raja Grafindo Persada 2002)

Satochid Kartanegara, Hukum Pidana, Kumpulan Kuliah Bagian Dua, (Balai Lektur Mahasiswa 1998).

\section{Jurnal/Artikel}

Sigit Martono, "Perlindungan Hukum bagi Pihak Ketiga yang Berikhtikad Baik Sehubungan dengan Penyitaan dan Perampasan asset dalam Perkara Tindak Pidana Korupsi dan Pencucian Uang (Studi Kasus: Putusan Pengadilan Tindak Pidana Korupsi No, 39/PID.SUS TPK 2013/PN/Jkt.Pst)", dalam Narasi: Kosakata Kosmetik Nurkholidah, FIB, UI, 2014, Januari 2015.

Abd Rahman Latief, Money Laundering Kaitannya Dengan Pemeriksaan Tindak Pidana Asal, e Jurnal Katalogis, Vol. 5, No 8, 2017.

\section{Laman}

Center for International Forestry Research, "Instrumen Anti Pencucian Uang", https://www.cifor.org/ilea/_ref/ina/instruments/Law_Enforcement/ antipencucianuang/index.htm, Juni 2010, diakses pada tanggal 23 Juli 2019.

HOW TO CITE: Widyanti Wibowo,'Perlindungan Hukum Pihak Ketiga Yang Beritikad Baik Dalam Tindak Pidana Pencucian Uang'(2019) Vol.2 No. 5 Jurist-Diction. 